Journal of Al Azhar University Engineering Sector

Vol. 11, No. 40, July, 2016, 1047-1054

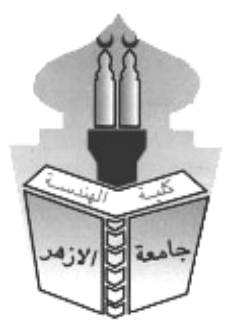

\title{
DEPENDENCY OF MICROSTRUCTURE EVOLUTION AND MECHANICAL DURABILITY ON SINTERING TEMPERATURE OF $\mathrm{W}_{-S_{F}}$ $_{\mathrm{F}}$ SIC $_{M}$ HYBRID COMPONENT
}

\author{
Waleed.A.Mohrez ${ }^{1}$, Ahmed Abdel Kareem ${ }^{1}$ and Hussein M. Abdelaziz ${ }^{2}$ \\ ${ }^{1}$ department of reactors materials, nuclear materials authority, Cairo Egypt, \\ ${ }^{2}$ mining and metallurgical department, Al-zhar university, Cairo, Egypt,
}

\begin{abstract}
Reinforced silicon carbide matrix by silicon carbide nano fibers, her after $\mathrm{SiC}_{\mathrm{f}} / \mathrm{SiC}_{\mathrm{m}}$; is a promising materials for nuclear fusion applications, due to the engineering aspects of the $\mathrm{SiC}_{\mathrm{f}} / \mathrm{SiC}_{\mathrm{m}}$ materials; related to its limited thermal conductivity and durability, it was indispensable to make cladding of $\mathrm{SiC}_{\mathrm{f}} / \mathrm{SiC}_{\mathrm{m}}$ substrate by higher thermally conductive, durable material such as Tungsten. This article discussed the conditions of the processing to produce durable joining between tungsten and $\mathrm{SiC}_{\mathrm{f}} / \mathrm{SiC}_{\mathrm{m}}$ by hot pressing technique. The article discussed the correlation between these conditions and the microstructure evolution of the product at the fusion layer. The correlation between microstructure evolution and mechanical properties of the produced hybrid component of $\mathrm{W}-\mathrm{SiC}_{\mathrm{f}} / \mathrm{SiC}_{\mathrm{m}}$ was studied as well.
\end{abstract}

\section{KEY WORDS: NITE PROCESS, LHD, PLASMA FACING MATERIALS, W- SIC $_{F} /$ SIC $_{M}$ HYBRID COMPONENT.}

\section{1- INTRODUCTION:}

It is indispensable to conduct a special technique for solid stat diffusion bonding between $\mathrm{W}$ and $\mathrm{SiC}_{\mathrm{f}} / \mathrm{SiC}_{\mathrm{m}}$, that purpose was achieved by nano infiltration transient eutectic (NITE process)[1-10] to produce hybrid component of $\mathrm{W}-\mathrm{SiC}_{\mathrm{f}} / \mathrm{SiC}_{\mathrm{m}}$, this hybrid component showed a promising and attractive properties during it is divertor plasma exposure test inside the large helical device(LHD)[11,12], the long term design aspect will take in consideration decreasing the thermal shocks resulting not only from quasi-steady state plasma, but also from the thermal load resulting from off -normal events[13].more precise investigation of the processing conditions of $\mathrm{W}-\mathrm{SiC}_{\mathrm{f}} / \mathrm{SiC}_{\mathrm{m}}$ and the dependency of mechanical and micro structure evolution on such processing condition is highly recommended aspect shall take on consideration; to reach to the optimum and sufficient data to produce durable bonded hybrid structure of $\mathrm{W}-\mathrm{SiC}_{\mathrm{f}} / \mathrm{SiC}_{\mathrm{m}}$. This article showed the data of processing; five samples of $\mathrm{W}$ $\mathrm{SiC}_{\mathrm{f}} / \mathrm{SiC}_{\mathrm{m}}$ by hot press(HP) technology and studied the microstructure of three samples at their fusion bonding layer, the five samples were mechanically tested in destructive way; to show the correlation between the microstructure evolution with the mechanical test results

\section{2- THE EXPERIMENTAL WORK}

\section{2-1- preparation of the starting materials}

The starting materials of the test samples are tungsten powder and $\mathrm{SiC}_{\mathrm{f}} / \mathrm{SiC}_{\mathrm{m}}$ preform, where the dimensions of the preform is $40 \mathrm{~mm}^{*} 40 \mathrm{~mm} * 5.5 \mathrm{~mm}$ sheet has been fabricated as shown in Fig.1 with fibers of Tyranno ${ }^{\mathrm{TM}}$-SA grade3, The preform is arranged as in Fig.1 inside the graphite mold where eventually the preform surrounded by graphite plates and 
carbon sheets to prevent sample to be stacked, the boron nitride sprayed between the graphite plates to facilitate releasing the sample after hot pressing process. The pure tungsten powder of purity $99.99 \%$ with rang size of $0.6-0.99 \mu \mathrm{m}$ with total weight 61.76 gm was piled and distributed above the preform

\section{Fabrication flow chart}

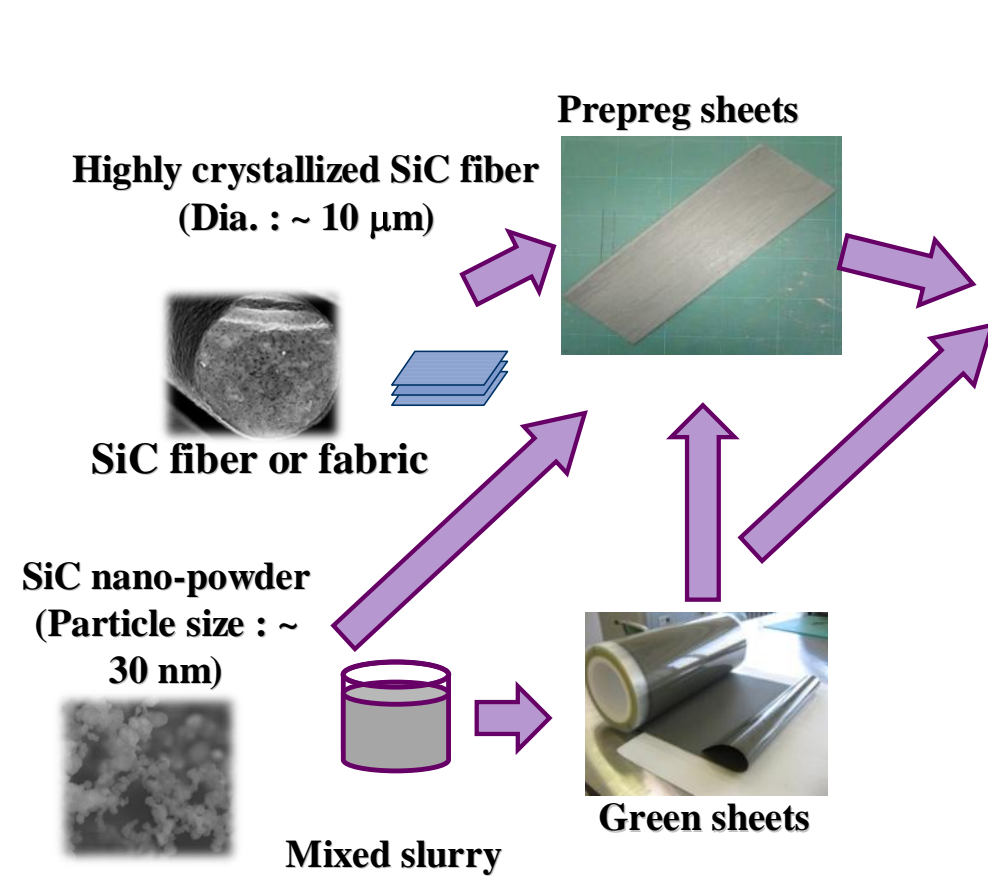

Hot pressing with 1870 C\& 20 MPa

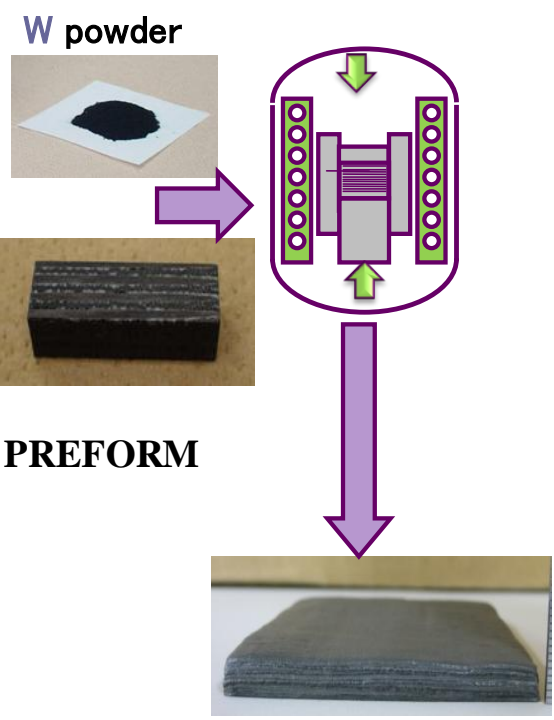

Final product of $\mathrm{W} / \mathrm{SiC} / \mathrm{SiC}$

Fig.1. Flow chart of the original NITE process

\section{2-2 Hot -press operating condition}

The hot pressing operating conditions representing on the temperature and applied pressure; The trial samples were fabricated with temperatures are ranging from $1700^{\circ} \mathrm{C}$ to $1900^{\circ} \mathrm{C}$, where five trial samples were fabricated; using temperatures; $1700{ }^{\circ} \mathrm{C}, 1750{ }^{\circ} \mathrm{C}, 1800{ }^{\circ} \mathrm{C}, 1850$ ${ }^{\circ} \mathrm{C} 1900^{\circ} \mathrm{C}$, all these samples were subjected to a constant heatin up rate up to it is maximum degree, then each sample was holded atit is maximum temperatur for one hour,during heating up of each sample a synchronized pressure was applied with a constant rate, till maximum pressure up to $20 \mathrm{Mpa}$, then the hot press holded the applied pressure for one hour [14] the conditions of each sample are illustrating in table (1) 
DEPENDENCY OF MICROSTRUCTURE EVOLUTION AND MECHANICAL DURABILITY ON SINTERING TEMPERATURE OF W-SIC FIS $_{M}$ HYBRID COMPONENT

Table (1). Specification of the hot press machine

\begin{tabular}{|c|c|c|c|c|}
\hline $\begin{array}{c}\text { Sample } \\
\text { No. }\end{array}$ & $\begin{array}{c}\text { Applied } \\
\text { temperatute }\left({ }^{\mathbf{0}} \mathrm{C}\right)\end{array}$ & $\begin{array}{c}\text { Holding temperature } \\
\text { time(minutes) }\end{array}$ & $\begin{array}{c}\text { Applied } \\
\text { pressure(MPa) }\end{array}$ & $\begin{array}{c}\text { Holding pressure } \\
\text { time(minutes) }\end{array}$ \\
\hline 1 & 1700 & 60 & 20 & 60 \\
\hline 2 & 1750 & 60 & 20 & 60 \\
\hline 3 & 1800 & 60 & 20 & 60 \\
\hline 4 & 1850 & 60 & 20 & 60 \\
\hline 5 & 1900 & 60 & 20 & 60 \\
\hline
\end{tabular}

Hot pressing machine is shown in Fig.2 - model (FVPHP-R-5-FRET-15), the Specification of the hot press machine is illustrated in table (2), the graphite mold of the hot press was used for fabrication the starting materials as illustrating in Fig.1.

Table (2). Specification of the hot press machine

\begin{tabular}{|c|c|c|c|c|c|c|c|}
\hline Model & $\begin{array}{c}\text { Max } \\
\text { temperature }\end{array}$ & $\begin{array}{c}\text { Heating } \\
\text { time }\end{array}$ & $\begin{array}{c}\text { Mold } \\
\text { dimensions }\end{array}$ & Vacuum & $\begin{array}{l}\text { Atmosphere } \\
\text { pressure }\end{array}$ & $\begin{array}{c}\text { Press } \\
\text { pressure }\end{array}$ & $\begin{array}{c}\text { Electric } \\
\text { power }\end{array}$ \\
\hline $\begin{array}{c}\text { FVPH } \\
\text { P-R- } \\
\text { 5FRE } \\
\text { T-155 }\end{array}$ & $1900^{\circ} \mathrm{C}$ & $\begin{array}{c}40 \\
\text { minute } \\
\text { R.T to } \\
1500^{0} \mathrm{c}\end{array}$ & $\begin{array}{l}\text { Ф } 120 \mathrm{~mm} \\
\text { H } 110 \mathrm{~mm}\end{array}$ & $\begin{array}{c}1 * 10^{-4} \\
\text { pa }\end{array}$ & $\begin{array}{c}0.92 \text { M.pa } \\
\mathrm{N}_{2}, \mathrm{Ar}\end{array}$ & $\begin{array}{c}4.9 * 10^{4} \\
\mathrm{~N}\end{array}$ & $\begin{array}{l}220 \mathrm{~V} \\
15 \mathrm{KW}\end{array}$ \\
\hline
\end{tabular}

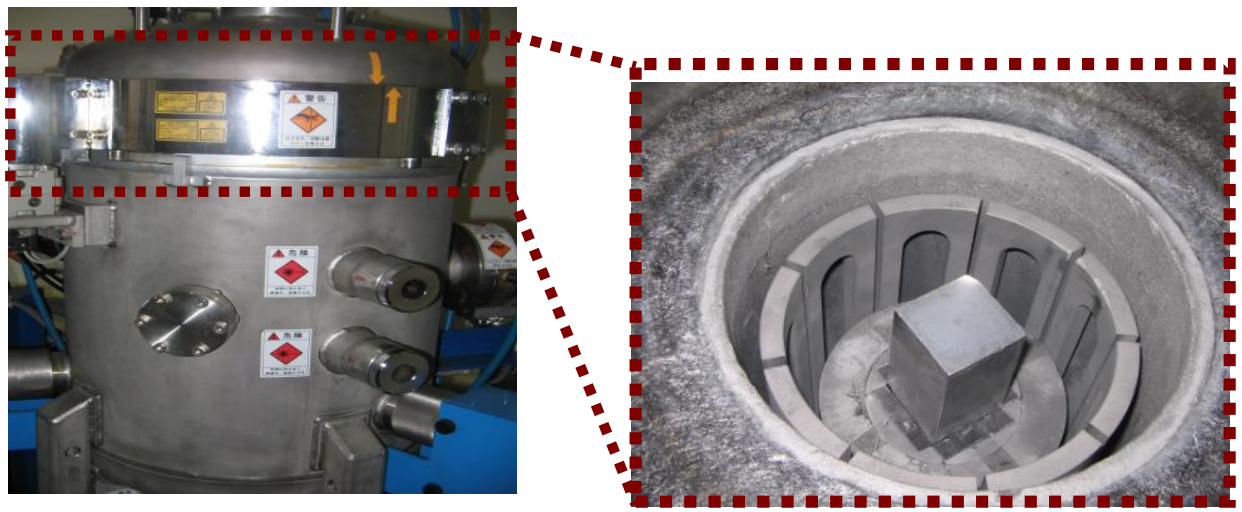

Fig.2. Hot press machine and its inner mold

\section{2-3-Samples take out and preparation}

After finishing the sintering by hot press of each sample according to the above mentioned conditions,the five samples; Nos: 1, 2, 3, 4, 5 were taken out and prepared for subsequence tests, where taken out samples were polished and grinded by rotation polishing technique(LOGITEC PM5 ) to the smooth surface and texture of both side of tungsten and $\mathrm{SiCf} / \mathrm{SiCm}$, as illustrated in the Fig.3. 

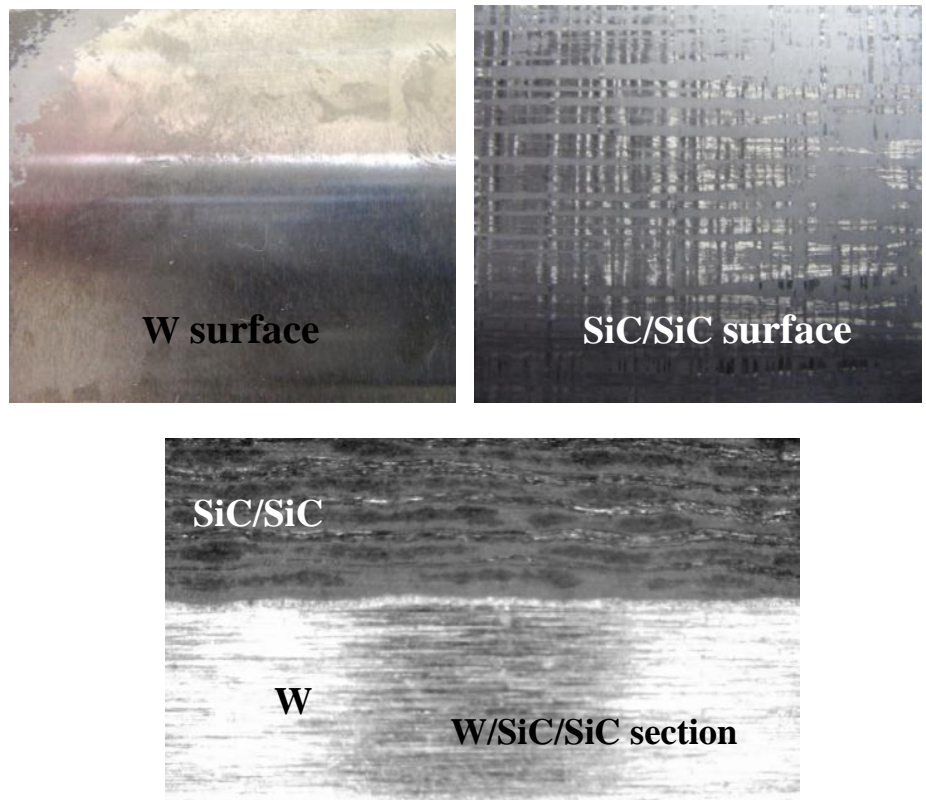

Fig.3. test sample showed the surface of both $\mathrm{SiC}_{\mathrm{f}} / \mathrm{SiC}_{\mathrm{m}}$ and $\mathrm{W}$ and cross section

\section{3-RESULTS AND DISCUSSION}

\section{3-1Microstructure evolution}

All test samples were examined at the cross section of tungsten- $\mathrm{SiCf} / \mathrm{SiCm}$ interphase layer, to investigate the microstructure evolution; on the reaction layer between tungsten and $\mathrm{SiCf} / \mathrm{SiCm}$, the microstructure investigation showed that; there was a phenomenal change in the interphase layer thickness, due to different processing conditions of sintering temperature. The relation between sintering temperature and the thickness of the reaction layey is illustraed in table.3. where at sintering temperature of sampl "1" at $1700^{\circ} \mathrm{C}$; showed reaction layer thickness up to $25 \mu \mathrm{m}$,wherease the samples "2","3","4","5" with sintering temperatures: $1750^{\circ} \mathrm{C}, 1800^{\circ} \mathrm{C}, 1850^{\circ} \mathrm{C}, 1900^{\circ} \mathrm{C}$, showed a thicknesses of reaction layer: $33,40,45,78 \mu \mathrm{m}$ respectively.Fig.4. showed the microstructure evolution of the reaction layer of samples "1","2","3","4","5",where slightly increase in thickness of reaction layer was observed in samples; $1,2,3,4$, wherease high acclertaed increase was demonstrated in samle 5

Table(3). the correlation between sintering temperature and thickness of reaction layer

\begin{tabular}{|c|c|c|c|}
\hline Sample No & $\begin{array}{c}\text { Sintering } \\
\text { Temperature }\left({ }^{\circ} \mathrm{C}\right)\end{array}$ & $\begin{array}{c}\text { Thickness of the } \\
\text { reaction layer }(\mu \mathrm{m})\end{array}$ & comment \\
\hline 1 & 1700 & 28 & Slight increase \\
\hline 2 & 1750 & 33 & Slight increase \\
\hline 3 & 1800 & 40 & Slight increase \\
\hline 4 & 1850 & 45 & Slight increase \\
\hline 5 & 1900 & 78 & Accelerated growth \\
\hline
\end{tabular}
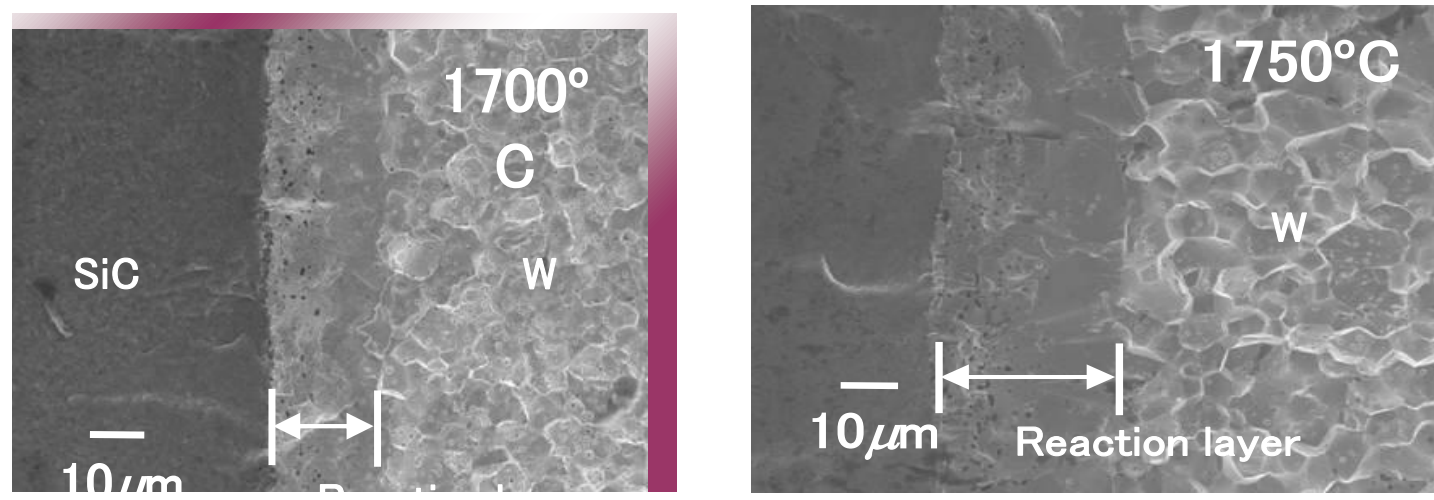

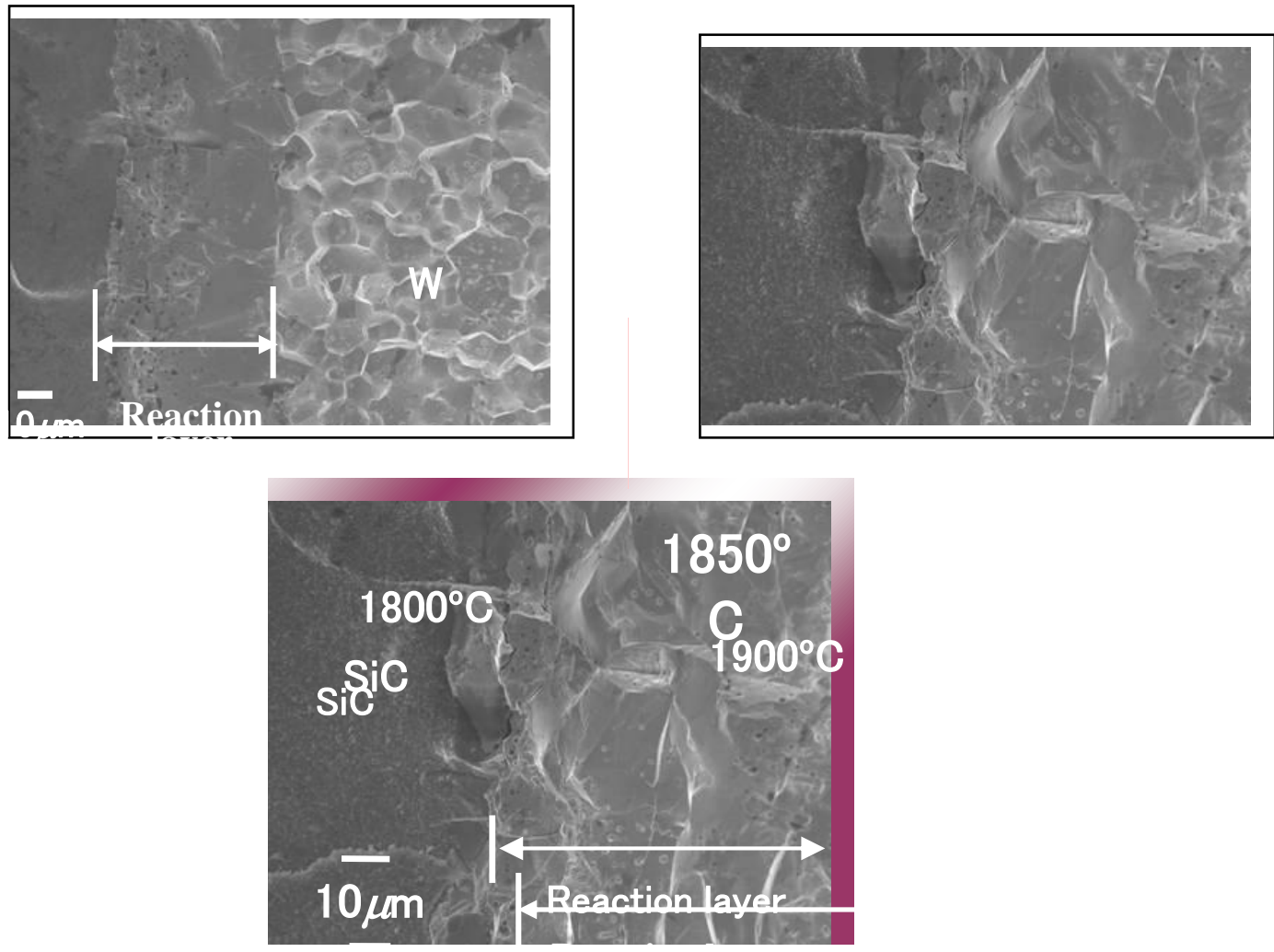

Fig.4. the microstructure evolution of the reaction layer of three samples, with different sintering

\section{3-2 Flexural strength test}

\section{temperatures}

Five hot pressed samples were tested mechanically by three point bending test, where the five samples; with different sintering temperature " $1 "\left(1700^{\circ} \mathrm{C}\right)$ "2"(1750 $\left.{ }^{\circ} \mathrm{C}\right), " 3 "\left(1800^{\circ} \mathrm{C}\right), " 4 "\left(1850^{\circ} \mathrm{C}\right), " 5^{\prime \prime}\left(1900^{\circ} \mathrm{C}\right)$ was bended by the device of 5581, Instron Inc with a cross head speed: $0.5 \mathrm{~mm} / \mathrm{min}$, specimen size: $22 \times 2 \times 2[\mathrm{~mm}]$ as shown in the Fig.5. The results of the flexural strength of the bended samples are shown in Fig.6, where, the correlation between sintering temperature and value of flexural strength behaved as proportional linear function, where the values of flexural strength at $1700^{\circ} \mathrm{C}, 1750^{\circ} \mathrm{C}, 1800^{\circ} \mathrm{C}$, were $680,1050,1150 \mathrm{Mpa}$ respectively, on the other hand when the sintering temperature commenced to be elevated after $1800^{\circ} \mathrm{C}$, it showed non-proportional linear function correlation with the values of flexural strength, where after $1800^{\circ} \mathrm{C}$ to $1850^{\circ} \mathrm{C}$ showed slight deterioration of the flexural strength values from $1150 \mathrm{MPa}$ to $1050 \mathrm{MPa}$, after $1850^{\circ} \mathrm{C}$ to $1900^{\circ} \mathrm{C}$ showed catastrophic deterioration in flexural strength from 1050 to 500 Mpa.

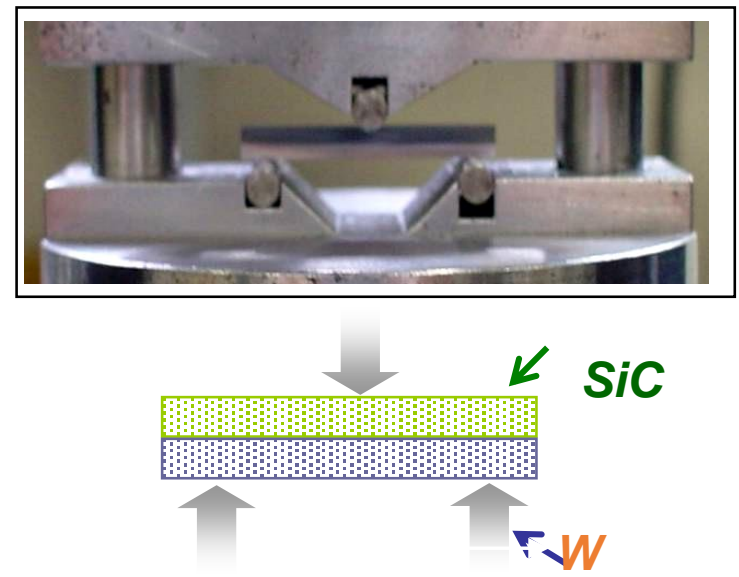

Fig. 5. device of three point bending test 


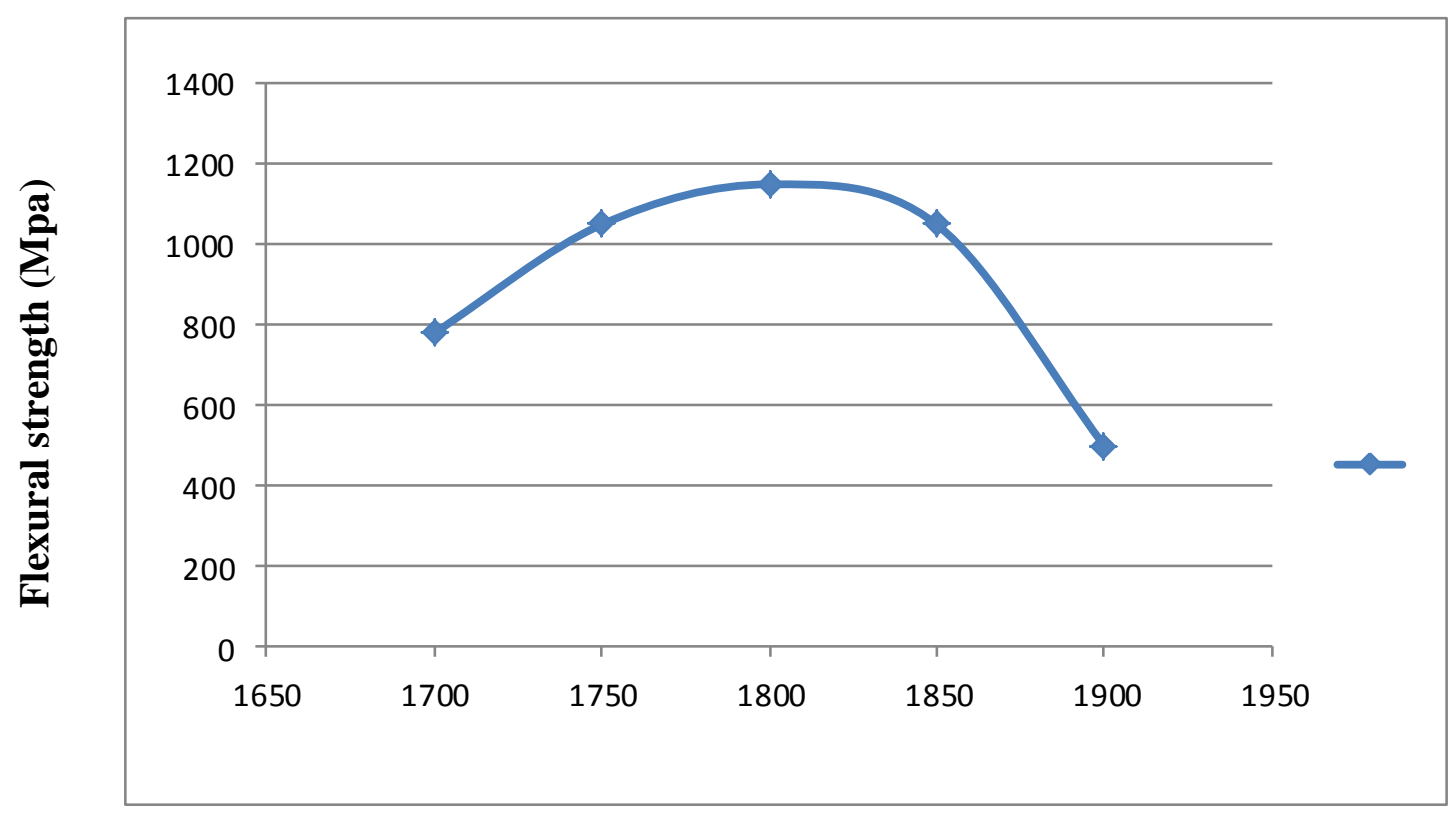

Fig.6. Correlation between sintering temperature and Flexural strength.

\section{3-3-Chemical analysis of the interphase layer and its relation with the flexural strength .}

Each processed sample was tested by XRD method in the region of the reaction layer, to make the correlation between the chemical phases appeared on the reaction layer and the mechanical test results of the flexural strength, where the results of XRD due to the analyses of each SEM images(Fig.7); are tabulated on the table.(4) the chemical analyses, could clearly interpretate the behavior of the flexural strength of each sample where as seen in table(4) the samples; 1,2 , with fabrication temperatures $; 1700^{\circ} \mathrm{C}, 1750^{\circ} \mathrm{C}$ respectively, showed the occurrence of phases; $\mathrm{W}_{2} \mathrm{C}, \mathrm{WC}$, WSi2, wherease the samples 3,4,5 with fabrication temperature; $1800^{\circ} \mathrm{C}, 1850{ }^{\circ} \mathrm{C}, 1900^{\circ} \mathrm{C}$ respectively, showed a disappearing of the phase $\left(\mathrm{WSi}_{2}\right)$, and domination of the phase $\left(\mathrm{W}_{5} \mathrm{Si}_{3}\right)$, which it's astrong evidence that the deterioration of the flexural strength after temperature $1800^{\circ} \mathrm{C}$ was due to the domination of the phase $\mathrm{W}_{5} \mathrm{Si}_{3}$ and disappearing of the phase $\left(\mathrm{WSi}_{2}\right)$.

Table (4). X-Ray analysis of the reaction layer at different sintering temperatures

\begin{tabular}{|c|c|c|c|}
\hline Sintering temperature $\left({ }^{\circ} \mathrm{C}\right)$ & \multicolumn{3}{|c|}{ XRD phases appeared in the interphase layer } \\
\hline 1700 & $\mathbf{W}_{2} \mathbf{C}$ & WC & $\mathbf{W S i}_{2}$ \\
\hline 1750 & $\mathbf{W}_{2} \mathbf{C}$ & WC & $\mathbf{W S i}_{2}$ \\
\hline 1800 & $\mathbf{W}_{2} \mathbf{C}$ & $\mathrm{W}_{5} \mathrm{Si}_{3}$ & WC \\
\hline 1850 & $\mathbf{W}_{2} \mathbf{C}$ & $\mathbf{W}_{5} \mathrm{Si}_{3}$ & WC \\
\hline 1900 & $\mathbf{W}_{2} \mathbf{C}$ & $\mathrm{W}_{5} \mathrm{Si}_{3}$ & WC \\
\hline
\end{tabular}


DEPENDENCY OF MICROSTRUCTURE EVOLUTION AND MECHANICAL DURABILITY ON SINTERING TEMPERATURE OF W-SIC ${ }_{F}$ SSIC $_{M}$ HYBRID COMPONENT
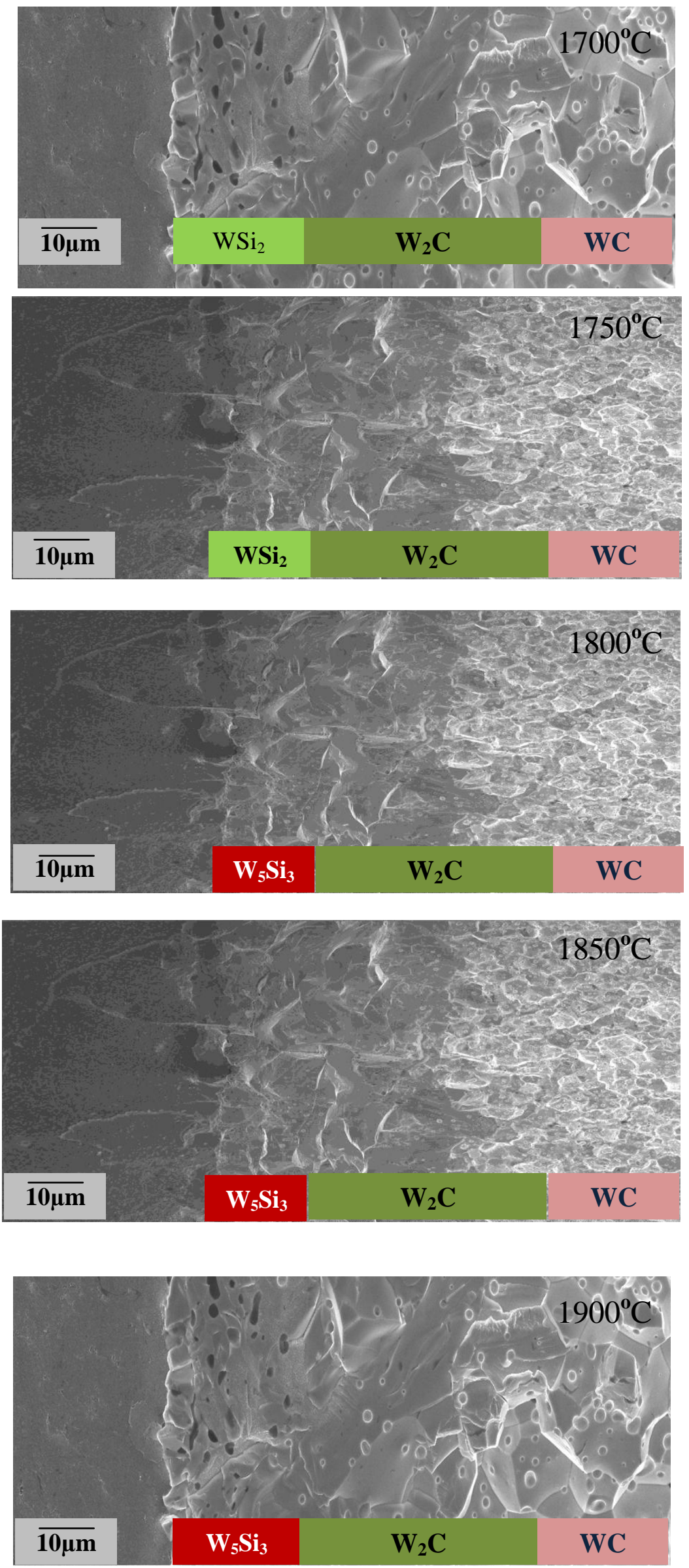

Fig.7. SEM images showing XRD of reaction layer of three samples of different sintering 


\section{4-CONCLUSION}

The results of the analyzed data showed that; the durability of the $\mathrm{W}-\mathrm{SiCf} / \mathrm{SiCm}$ hybrid component doesn't depend only on the thickness of the reaction layer, due to increasing the sintering temperature, but it depends alse on the chemical composition of the formed reaction layer in the interphase region, where the optimum sintering temperature which showed threshold of the maximum flexural strength, up to $1150 \mathrm{Mpa}$ at $1800^{\circ} \mathrm{C}$, due to the substitution of the phase " $\mathrm{WSi}_{2}$ " by the phase " $\mathrm{W}_{5} \mathrm{Si}_{3}$ ", the last phase dominated with increasing the sintering temperature, which resulting to the catastrophic deterioration of the mechanical flexural strength at the temperature of $1900^{\circ} \mathrm{C}$, from $1050 \mathrm{Mpa}$ to $500 \mathrm{MPa}$, due to the domination of the phase " $\mathrm{W}_{5} \mathrm{Si}_{3}$ ". According to the resulting data; it is strongly recommended to conduct the sintering at the temperature $1800^{\circ} \mathrm{C}$ at pressure $20 \mathrm{MPa}$ for holding time $1 \mathrm{hr}$.

\section{REFERENCES}

1. Yi-Hyun Park, Joon-Soo Park, Tatsuya Hinoki, Akira Kohyama. "Development of manufacturing method for NITE-porous SiC ceramics using decarburization process". Journal of the European Ceramic Society, Volume 28, Issue 3, 2008, Pages 657-661.

2. K. Shimoda, J.S. Park, T. Hinoki, A. Kohyama. Microstructural optimization of hightemperature $\mathrm{SiC} / \mathrm{SiC}$ composites by NITE process. Journal of Nuclear Materials, Volumes 386-388, 30 April 2009, Pages 634-638.

3. Kazuya Shimoda, Akira Kohyama, Tatsuya Hinoki. High mechanical performance $\mathrm{SiC} / \mathrm{SiC}$ composites by NITE process with tailoring of appropriate fabrication temperature to fiber volume fraction. Composites Science and Technology, Volume 69, Issue 10, August 2009, Pages 1623-1628.

4. Takaaki Koyanagi, Sosuke Kondo, Tatsuya Hinoki. The influence of sintering additives on the irradiation resistance of NITE SiC. Journal of Nuclear Materials, Volume 417, Issues 1-3, 1 October 2011, Pages 435-439.

5. Hun-Chea Jung, Tatsuya Hinoki, Yutai Katoh, Akira Kohyama. Development of a shear strength test method for NITE-SiC joining material.Journal of Nuclear Materials, Volume 417, Issues 1-3, 1 October 2011, Pages 383-386

6. Joon-Soo Park, Akira Kohyama, Tatsuya Hinoki, Kazuya Shimoda, Yi-Hyun Park. Efforts on large scale production of NITE-SiC/SiC composites. Journal of Nuclear Materials, Volumes 367-370, Part A, 1 August 2007, Pages 719-724.

7. H. Kishimoto, K. Ozawa, O. Hashitomi, A. Kohyama. Microstructural evolution analysis of NITE SiC/SiC composite using TEM examination and dual-ion irradiation. Journal of Nuclear Materials, Volumes 367-370, Part A, 1 August 2007, Pages 748-752.

8. Genichiro Matsuo, Tamaki Shibayama, Hirotatsu Kishimoto, Kouichi Hamada, Seiichi Watanabe. Micro-chemical analysis of diffusion bonded W-SiC joint. Journal of Nuclear Materials, Volume 417, Issues 1-3, 1 October 2011, Pages 391-394.

9. B.S. Sammuli, M.L. Walker, D.A. Humphreys, J.R. Ferron, R.D. Johnson, B.G. Penaflor, D.A. Piglowski, S.H. Hahn, J. Hong, B. Xiao, Q. Yuan. Approaches to tokamak offnormal event detection and response at DIII-D, KSTAR, and EAST. Fusion Engineering and Design, Volume 85, Issues 3-4, July 2010, Pages 456-460.

10. S.P Lee, H.K Yoon, J.S Park, Y Katoh, A Kohyama, D.H Kim, J.K Lee. Reaction sintering process of tyranno $\mathrm{SA} / \mathrm{SiC}$ composites and their characterization

11. Waleed A. Mohrez, Hirotatsu Kishimoto, Yutaka Kohno, S. Hirotaki, Akira Kohyama. Behavior of $\mathrm{W}-\mathrm{SiC} / \mathrm{SiC}$ dual layer tiles under LHD plasma exposure. Journal of Nuclear Materials, Volume 442, Issues 1-3, November 2013, Pages 382-388.

12. Waleed Alsayed Mohrez, Akira Kohyama, Hirotatsu Kishimoto, Yutaka Kohno. Effect of $10 \mathrm{MW} / \mathrm{m}^{2}$ plasma exposure on W-SiC/SiC dual layer tiles. Fusion Engineering and Design, Volume 88, Issues 9-10, October 2013, Pages 1655-1659.

13. A.Hassanein, G. Federici, I. Konkashbaev, A. Zhitlukhin, V. Litunovsky. Materials effects and design implications of disruptions and off-normal events in ITER. Fusion Engineering and Design, Volumes 39-40, 1 September 1998, Pages 201-210.

14. S.J Son, K.H Park, Y Katoh, A Kohyama.Interfacial reactions and mechanical properties of $\mathrm{W}-\mathrm{SiC}$ in-situ joints for plasma facing components. Journal of Nuclear Materials, Volumes 329-333, Part B, 1 August 2004, Pages 1549-1552 